\title{
Core Histone Macro-H2A.1
}

National Cancer Institute

\section{Source}

National Cancer Institute. Core Histone Macro-H2A.1. NCI Thesaurus. Code C113624.

Core histone macro-H2A.1 (372 aa, $\sim 40 \mathrm{kDa}$ ) is encoded by the human MACROH2A1 gene. This protein plays a role in chromatin modification. 